\title{
Syllabus Design for Writing Course: EFL Learners' Needs
}

\author{
M. Fadhly Farhy Abbas ${ }^{1)}$, Hermawati Syarif ${ }^{2)}$ \\ ${ }^{1)}$ Universitas Lancang Kuning, ${ }^{2)}$ Universitas Negeri Padang \\ e-mail: fadhly@unilak.ac.id ${ }^{1}, \underline{\text { hermawati_sy@yahoo.com }}{ }^{2}$
}

\begin{abstract}
Analyzing English as Foreign Language (EFL) learners' needs in writing courses is an important thing that should be done by teachers. This is done in order to meet what EFL learners needs for writing course, and what should be planned and written in the syllabus. The purpose of this research is to analyze EFL learners' needs for writing course especially in terms of learning materials, learning strategies, learning supports, and mastery of writing aspects. The design of this research was descriptive research. 50 EFL learners in Universitas Lancang Kuning were involved in this study as respondents of this research. To collect the data, a questionnaire was used with 20 statements available. The data from the questionnaire was analyzed descriptively by giving deep explanation towards the data. The result showed that most EFL learners were chosen response "agree" from the questionnaire. It means that the EFL learners very need good and acceptable learning materials, learning strategies, learning supports, and good competence in terms of writing aspects. In conclusion, the EFL learners' needs for writing course are varied, but in general, the EFL learners expect good learning environment for writing course such as utilizing appropriate technology, attractive teaching media, and acceptable learning materials.
\end{abstract}

Keywords: Syllabus design, writing course, EFL learners' needs, learning environment

\section{Introduction}

Writing skill is still one of the most feared skills by language learners, especially for EFL learners at the university level. This is because the writing skill requires many other abilities or competencies, such as the ability to find ideas that match the theme or topic, the ability to use correct grammar, the ability to use the right choice of words, the skills in using punctuation marks, or the correct use of spelling. When a piece of writing is not equipped with proper punctuation or spelling, then the writing will become less meaningful and even completely wrong. In contrast to other language skills, such as speaking skills, listening skills, and reading skills, they do not require complex abilities as found in writing skills.

In accordance with the statement above, Abbas \& Herdi (2018), Nosratinia \& Nikpanjeh (2019), and Agustiana (2016) also stated that writing skill is more difficult skill than the other three language skills, namely speaking skill, listening skill, and reading skill as previously described. There are two aspects that need to be seriously considered by the writers before they start their writing. This aspect is known as the writing process and micro and macro skills in writing (micro-macro skills of writing). The writing process emphasizes more on the stages in writing such as drafting, revising, editing, and publishing. And, micromacro skills of writing focus more on the use of linguistic aspects or language components and proper writing mechanisms.

In this millennial era, learning writing skill is required to be more integrated with technology so that learning writing skill becomes creative and fun (Bakri \& Yusni, 2021; Fitriani, Haryadi, Pristiwati, 2021; Herman, Ramly, Daeng, Raya \& Selatan, 2021; Muthoharoh \& Prastyaningsih, 2020; Sitorus, 2019; Suciartini \& Sumartini, 2019). If not, this will have an impact on the decreasing interest of students in 
writing. Therefore, the students' needs in writing course should be investigated more. This investigation is also needed by teachers in designing good syllabus for teaching writing. For this reason, the role of technology in learning writing skills is needed. There are many learning platforms that can be used in learning writing skills. One of the famous platforms is Edmodo. Edmodo is a learning application that is able to lead students to be more active in the learning process. In addition, Edmodo also has complete features that can attract students' interest in the learning process. Abbas \& Yusuf (2020) added that Edmodo can direct students to be able to write, do assignments, and do quizzes well. As a result, by integrating technology, it can meet students' need for writing course and it can be a basic reason to design good syllabus for writing course.

Besides the role of technology, creative and fun learning in writing activities can also be caused by the influence of the right learning model. There are many learning models that can be used in the learning process. One of the learning models that can be used in learning writing skills is a project-based learning (PjBL) model. Furthermore, Syukria (2019) explained that PjBL is an innovative learning model that emphasizes students to learn contextually through complex and real activities. In other words, appropriate learning model can be one of the reasons to investigate students' need and to create creative and active learning in writing.

To be able to produce creative writing skills learning, a preliminary study called needs analysis is needed. Through this needs analysis activity, a teacher/lecturer and students/learners can find and determine what things are needed in learning writing skill. Generally, the need for learning writing skill is related to teaching materials, competencies, media, learning facilities or technology, and so on. This is in line with what has been stated by Ilham, Musthafa, \& Yusuf (2020) that in learning writing skills, there are three general needs of students that need to be considered, namely necessities (needs), lacks (lack), and wants (desire). Necessities focuses on what materials or materials are needed by students/students, lacks focuses on the weak points of students/students in writing that need improvement, and wants focuses on what is desired to realize creative writing skills learning.

There are so many previous studies that examine the needs analysis in this writing skill. Theoretically, this relevant study is needed to support this paper. The relevant studies include those that have been carried out by (Ampa \& Quraisy, 2018; Fareed, Ashraf, \& Bilal, 2016; Sumarsono, Bagis, \& Arrafii, 2017; Tjalla, Akil, \& Hamra, 2017; Yundayani, 2018; Yundayani, Emzir, \& Rafli, 2017). These previous researchers studied needs analysis in learning writing skill to make learning more active, creative, and fun. The deeper the needs analysis study on writing skills is carried out, of course, the better and creative writing skill learning will be produced. In addition, the author also tried to find the expectations of students in terms of improving students' abilities and interests in writing. Thus, this makes this research different from the previous studies that have been described previously.

Based on the previous explanations, the author also has an interest in investigating EFL learners' needs in learning writing skills. This is because the author is also a teacher (lecturer) who also teaches writing skills courses. As someone who teaches writing skills courses, of course this is become the responsibility of the author in managing and creating better environment for teaching writing skills. With the needs analysis in the form of this research, the authors can synergize with the research results obtained to organize and improve the quality of teaching writing in the future time. Therefore, the purpose of this research is to investigate EFL learners' needs in learning writing skill, especially for essay writing course. Furthermore, these needs analysis are used as basic considerations to design appropriate syllabus for essay writing course. In short, it is expected that by having the needs analysis, the teaching of essay writing will be better and better.

\section{Methods}

In this study, the author used a descriptive research design. There were 50 EFL learners involved in this research. The learners were from English Education Department of Universitas Lancang Kuning, Pekanbaru, Indonesia. To collect data, the author used a questionnaire consisting of 20 statements related to what things 
were needed by EFL learners in learning writing skill. This questionnaire was distributed virtually (online) using the Google form application. Then, the EFL learners were assigned to give response based on the statements given in the questionnaire. Furthermore, the data from this questionnaire was analyzed descriptively by giving deep explanations towards the data obtained.

\section{Result and Discussion}

The results of this study can be presented based on the results of the questionnaire that has been distributed. Based on the results of the questionnaire, there were various responses from students. Some of the students were chosen the response "strongly agree (sangat setuju), agree (setuju), hesitate (ragu-ragu), disagree (tidak setuju), and strongly disagree (sangat tidak setuju)" to the statements submitted through the questionnaire. The student responses were related to the needs and expectations of what they need in learning writing skills. Furthermore, the results of the questionnaire can be presented in the form of the following table.

Table 1. Recapitulation and Percentage of Student Responses

\begin{tabular}{ccccccccccc}
\hline Statements & \multicolumn{4}{c}{ Responses (\%) } & \multicolumn{6}{c}{ Total of Responses (students) } \\
& SS & S & RR & TS & STS & SS & S & RR & TS & STS \\
\hline 1 & 28 & 72 & - & - & - & 14 & 36 & - & - & - \\
2 & 22 & 76 & - & 2 & - & 11 & 38 & - & 1 & - \\
3 & 28 & 72 & - & - & - & 14 & 36 & - & - & - \\
4 & 24 & 72 & 4 & - & - & 12 & 36 & 2 & - & - \\
5 & 22 & 68 & 6 & 4 & - & 11 & 34 & 3 & 2 & - \\
6 & 24 & 64 & 8 & 2 & 2 & 12 & 32 & 4 & 1 & 1 \\
7 & 20 & 76 & 4 & - & - & 10 & 38 & 2 & - & - \\
8 & 24 & 74 & - & 2 & - & 12 & 37 & - & 1 & - \\
9 & 32 & 66 & 2 & - & - & 16 & 33 & 1 & - & - \\
10 & 40 & 56 & 4 & - & - & 20 & 28 & 2 & - & - \\
11 & 50 & 44 & 4 & 2 & - & 25 & 22 & 2 & 1 & - \\
12 & 32 & 60 & 8 & - & - & 16 & 30 & 4 & - & - \\
13 & 44 & 54 & 2 & - & - & 22 & 27 & 1 & - & - \\
14 & 32 & 56 & 10 & 2 & - & 16 & 28 & 5 & 1 & - \\
15 & 40 & 58 & - & - & 2 & 20 & 29 & - & - & 1 \\
16 & 30 & 64 & 4 & 2 & - & 15 & 32 & 2 & 1 & - \\
17 & 46 & 52 & 2 & - & - & 23 & 26 & 1 & - & - \\
18 & 40 & 58 & - & 2 & - & 20 & 29 & - & 1 & - \\
19 & 40 & 60 & - & - & - & 20 & 30 & - & - & - \\
20 & 32 & 66 & 2 & - & - & 16 & 33 & 1 & - & - \\
Average & 32.5 & 63.4 & 3 & 0.9 & 0.2 & 16.5 & 31.7 & 1.5 & 0.4 & 0.1 \\
Max & 50 & 76 & 8 & 4 & 2 & 25 & 38 & 5 & 2 & 1 \\
Min & 20 & 44 & 2 & 2 & 2 & 10 & 22 & 1 & 1 & 1 \\
\hline
\end{tabular}

\begin{tabular}{ll}
\hline Notes: & \\
SS & : Sangat Setuju \\
S & : Setuju \\
RR & : Ragu-ragu \\
TS & : Tidak Setuju \\
STS & : Sangat Tidak Setuju \\
Average : Nilai rata-rata \\
Max & : Nilai/angka terbesar \\
Min & : Nilai/angka terkecil
\end{tabular}

Language Learning Innovation in Pandemic Covid-19 Era 
Based on Table 1, it can be seen that on average, the response "strongly agree" the average score was $32.5 \%$. Then, for the response "agree" the average score was $63.4 \%$. Then, for the "hesitate" response the average score was 3\%, for the "disagree" response the average score was $0.9 \%$. And, for the response "strongly disagree" the average score was $0.2 \%$. Furthermore, it can also be seen that the largest percentage for the "strongly agree" response was 50\%. Then, the biggest percentage for "agree" responses was $76 \%$. Then, the largest percentage for the "hesitate" response was $8 \%$, the largest percentage for the "disagree" response was $4 \%$. And, the largest percentage for "strongly disagree" responses was $2 \%$.

In line with the percentage of the largest number, it can also be seen the percentage of the smallest number of each response. For the response "strongly agree" the smallest percentage was $20 \%$. Then, for the response "agree" the smallest percentage was $44 \%$. Then, for the "hesitate" response, the smallest percentage was $2 \%$, the smallest percentage for the "disagree" response was $2 \%$. And, for the response "strongly disagree" the smallest percentage was $2 \%$.

Based on the percentages described above, it can also be seen that the number of people who are the most and the fewest in choosing the available responses in the questionnaire. For the "strongly agree" response, the highest number who chose this response were 25 people, meaning that half $(50 \%)$ of the total class chose the response strongly agree to the number one statement, and there were at least 10 people. Furthermore, for the "agree" response, the highest number who chose this response was 38 people, and the minimum number was 22 people. This means that more than half $(50 \%)$ of the class chose this "agree" response. Then, for the "hesitate" response, the highest number who chose this response was only 5 people, and the minimum number was 1 person. For the "disagree" response, the highest number of people who chose this response was only 2 people, and the minimum number was 1 person. And, for the "strongly disagree" response, the most and the least number of learner who chose this response were only 1 person. Furthermore, the average number of people who chose each response is very difficult to explain because the number is not round.

As stated earlier, in addition to finding and analyzing the needs of students/students in learning to write, the author also finds the expectations of students/students in learning these writing skills. The data related to EFL learners' expectations in learning writing skills are found in the last three statements, namely numbers 18,19 , and 20. Based on the data that has been presented, it can be seen that the percentage of student responses to statements number 18,19 , and 20 is in the range of $32 \%$ to $66 \%$. This means that students have great expectations to be able to learn to write using modern media, technology, and teaching materials.

Based on the explanation of the results of the questionnaire that has been explained, the results of this questionnaire can also be presented in the form of a diagram to make it look simpler and more attractive. Furthermore, 3 diagrams can be presented that present data about the average percentage, the highest score or percentage, and the lowest percentage. Furthermore, these three diagrams can be seen as follows.

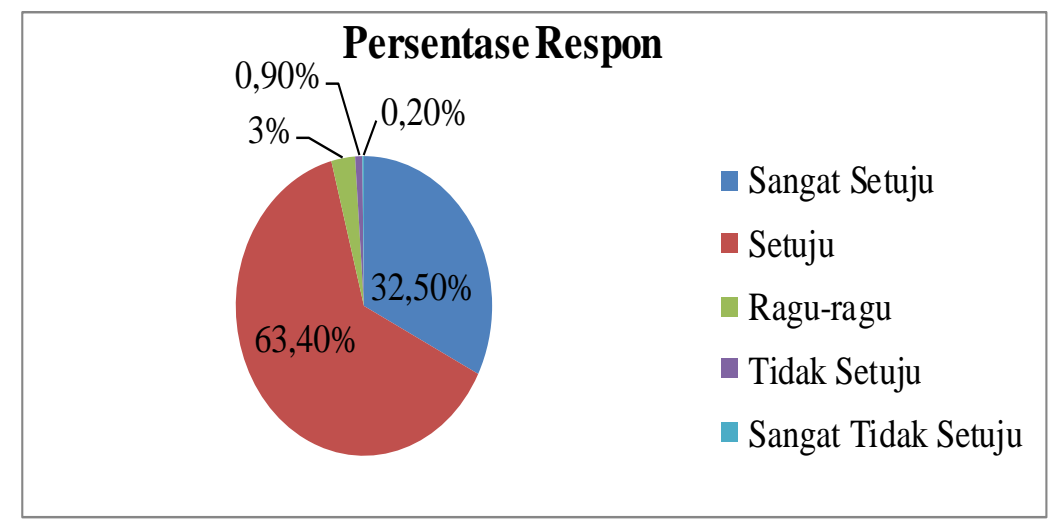

\section{Diagram 1. Average of Students' Responses}

Language Learning Innovation in Pandemic Covid-19 Era 


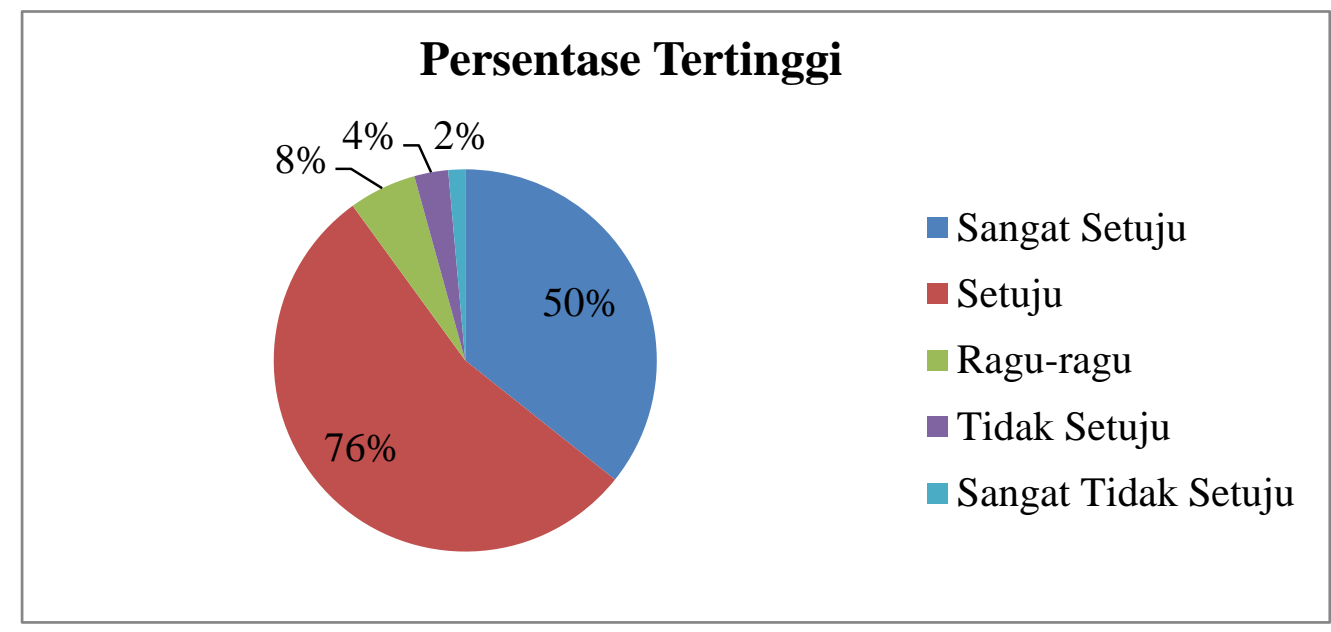

Diagram 2. The Highest Percentage

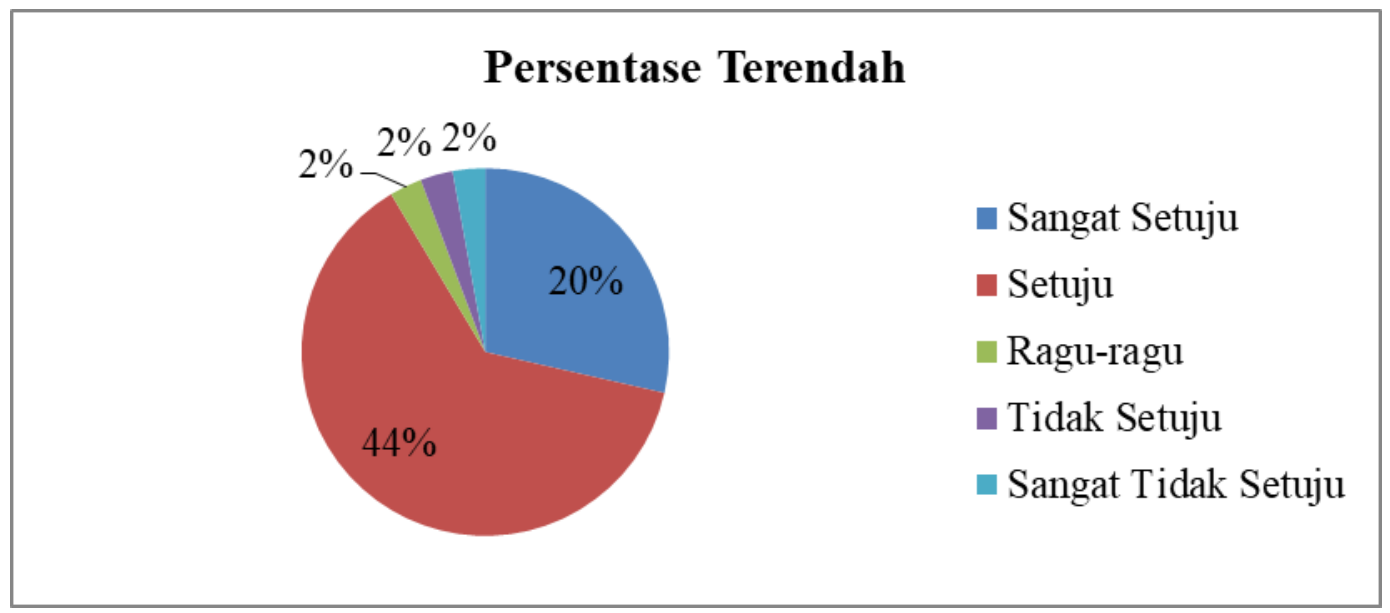

Diagram 3. The Lowest Percentage

Based on the three diagrams that have been presented previously, it can be seen that the average percentage of student responses to the questionnaire was $63.4 \%$ who stated "agree", $32.5 \%$ said "strongly agree", $3 \%$ said "hesitate", $0.9 \%$ " disagree", and $0.2 \%$ "strongly disagree". Then, for the highest percentage, 76\% said "agree", and 2\% said "disagree". From the presentation of this data, it can be stated that students are more likely to choose responses "agree" and "strongly agree" than other responses. This indicates that the needs of students in learning writing skills are very high. In short, students need to be guided by teaching materials that they really need in learning writing skills. In addition, students also need to be facilitated with interesting and fun media and technology.

In relation to the findings presented previously, it can be discussed and also stated that creative and fun learning for writing are become a must for writing instruction. This is done in order to meet the students' needs in learning writing. This is in line with previous research result done by Ilham, Musthafa, \& Yusuf (2020), Ampa \& Quraisy (2018), Fareed, Ashraf, \& Bilal (2016), Sumarsono, Bagis, \& Arrafii (2017), Tjalla, Akil, \& Hamra (2017), Yundayani (2018), Yundayani, Emzir, \& Rafli (2017) about active, creative and fun learning process. Furthermore, this is also supported by the research result conducted by Bakri \& Yusni (2021), Fitriani, Haryadi, Pristiwati (2021), Herman, Ramly, Daeng, Raya \& Selatan (2021), 
Muthoharoh \& Prastyaningsih (2020), Sitorus (2019), Suciartini \& Sumartini (2019) about creative and fun learning.

\section{Conclusion}

Based on the results and discussion of this study, it can be concluded that the needs of the EFL learners in learning writing skill are varied. This is indicated by the variety of responses chosen by these students in the questionnaires that have been distributed. Furthermore, it can also be stated that the EFL learners have high expectations for using appropriate technology, interesting media, and the selection of up-to-date and appropriate materials in the process of learning writing skills. In short, based on the EFL learners' needs and their expectations, the authors need to design good and appropriate syllabus for teaching of writing course in order to create creative and fun learning environment as well.

Based on the conclusions that have been presented previously, there are several suggestions that can be recommended as follows.

a. The EFL learners are suggested to maximize the results of the needs analysis from this research in the process of learning writing skills.

b. The teachers/lecturers are advised to really apply the things that are needed and expected by the EFL learners in the process of learning writing skills.

c. Future researchers are recommended to find new gaps from this research to be followed up into new research using different methods or designs, such as experimental research, classroom action research, research and development, or other types of research.

\section{Acknowledgments}

In this part, the author needs to express gratitude and many thanks to the persons contributed in this paper. The gratitude and thanks are basically goes to the institution where the author teaching and working, especially for all the elements of English Education Department, Faculty of Teacher Training and Education, Universitas Lancang Kuning Pekanbaru. Next gratitude is also addressed to Universitas Negeri Padang, the institution where the author pursue the Doctorate program, especially for all lecturers in Doctorate program of language pedagogy (S3 Ilmu Keguruan Bahasa), Universitas Negeri Padang, Indonesia.

\section{References}

Abbas, M. F. F., \& Herdi, H. (2018). Solving te students' problems in wiriting argumentative essay through collaborative writing strategy. English Review: Journal of English Education, 7(1), 105.

Abbas, M. F. F., \& Yusuf, S. S. M. D. (2020). The effect of edmodo in triggering students' recognition of recount text elements. Lectura: Jurnal Pendidikan, 11(1).

Agustiana, V. (2016). Combining product and process-based approaches to teaching writing discussion texts. English Review: Journal of English Education, 4(2).

Ampa, A. T., \& Quraisy, H. (2018). Needs analysis of the english writing skill as the base to design the learning materials. SHS Web of Conferences, 42(00050), 1-6.

Bakri, M., \& Yusni, Y. (2021). Pemanfaatan Youtube sebagai Media Pembelajaran Menulis Puisi. Silampari Bisa: Jurnal Penelitian Pendidikan Bahasa Indonesia, Daerah, Dan Asing, 4(1), 39-46. https://doi.org/10.31540/silamparibisa.v4i1.1183.

Fareed, M., Ashraf, A., \& Bilal, M. (2016). ESL learners' writing skills: Problems, factors and suggestions. Journal of Education \& Social Sciences, 4(2), 83-94. 
Fitriani, A.S., Haryadi, Pristiwati, R. (2021). Media mobile learning bermuatan kearifan lokal dalam menulis cerita pendek kelas IX SMA. Kode: Jurnal Bahasa, 10(2), 87-100.

Herman, H., Ramly, D., Daeng, J., Raya, T., \& Selatan, S. (2021). Pengaruh penggunaan media youtube terhadap keterampilan menulis teks prosedur. Indonesia: Jurnal Pembelajaran Bahasa Dan Sastra Indonesia, 2(2), 58-65.

Ilham, I., Musthafa, B., \& Yusuf, F. N. (2020). University students' needs of writing course materials: A case of Indonesia. English Review: Journal of English Education, 8(2), 195-207.

Muthoharoh., \& Prastyaningsih, H. (2020). Melestarikan budaya literasi karya sastra melalui literasi digital di era milenial. Lingua Rima: Jurnal Pendidikan Program Studi Bahasa Dan Sastra Indonesia, 9(1), 99-104.

Nosratinia, M., \& Nikpanjeh, N. (2019). Promoting foreign language learners' writing: Comparing the impact of oral conferencing and collaborative writing. English Review: Journal of English Education, $7(2), 17-26$.

Sitorus, J. P. (2019). Literasi Digital: Kontribusi dan tantangan dalam keterampilan menulis. Alfabeta: Jurnal Bahasa, Sastra, Dan Pembelajarannya, 2(2), 75-85.

Suciartini, N.N.A., \& Sumartini, N. L. P. . (2019). Pelatihan keterampilan mengkreasikan blog sebagai media menulis dan media dokumentasi budaya Bali. Widyabhakti: Jurnal Ilmiah Populer, 1(2), 72-80.

Sumarsono, D., Bagis, A. K., \& Arrafii, M. A. (2017). Students' needs to develop english writing materials. Lingua Cultura, 11(2), 67.

Syukria, A. U. (2019). Implementasi PjBL dengan media instagram pada keterampilan menulis bahasa Arab di SMA Islam P.B Soedirman 1 Bekasi. Prosiding Konferensi Nasional Bahasa Arab V, 389-399.

Tjalla, M., Akil, M., \& Hamra, A. (2017). The analysis of EFL students' needs for writing materials development. International Journal of Science and Research (IJSR), 6(8), 313-317.

Yundayani, A., Emzir, \& Rafli, Z. (2017). Need analysis: the writing skill instructional material context for academic purposes. English Review: Journal of English Education, 6(1), 59-70.

Yundayani, A. (2018). Present situation analysis: Students' early characteristics in writing for academic purposes. English Review: Journal of English Education, 6(2), 119-126. 